GHANA JOURNAL OF DEPARTMENT OF HEALTH, PHYSICAL EDUCATION AND RECREATION, SPORTS AND DANCE (GJOHPERSD)

Volume 7 \& 8, Year 2014 \& 2015

A JOURNAL OF THE DEPARTMENT OF HEALTH, PHYSICAL EDUCATION AND RECREATION (HPER)

UNIVERSITY OF CAPE COAST

GHANA, WEST AFRICA 


\title{
THE USE AND IMPACT OF ICT IN TEACHING AND LEARNING OF HEALTH EDUCATION IN ELEMENTARY SCHOOLS IN LAGOS STATE, NIGERIA
}

\author{
Blavo, Jude Femi \& Oroleeye, Adesoji Adeyemi \\ Dept of Physical and Health Education, \\ Adeniran Ogunsanya College of Education, Lagos, Nigeria. \\ Phone +234-802-387-9964, +234-702-859-6959, \\ E-mail-judeblavo@yahoo.com Sports Council, \\ Adeniran Ogunsanya College of Education, Lagos, Nigeria. \\ Phone +234-812-061-6095 \\ Email:sojioroleye@yahoo.com
}

\begin{abstract}
The study assessed the use and impact of Information and Communication Technology in teaching and learning of health education in elementary schools in Lagos State, Nigeria. A survey design was used for the study. The data were collected using self developed structured questionnaire, the co-variates collected in the questionnaire were: availability of ICT, adequate personnel and availability of funds, test-retest reliability co-efficient of 0.76 while purposive and stratified sampling technique was used to select the respondents and schools respectively. One thousand eight hundred and twenty six instruments were retrieved out of One thousand nine hundred and fifty distributed and statistics of mean, standard deviation and ANOVA were used to analyze the data. Results indicated that all the co-variates used in the study were significant. Showing a joint regression produced $F(6.1819)=83.188$, $P<0.05$. Since $p$ value is less than 0.05. Integrating information and communication technology into health Education is very.essential to improve the teaching and learning of health education in elementary schools in Lagos Nigeria.
\end{abstract}

Key words: Use, Impact, ICT, Health Education, Teaching and Learning. 
The use and Impact of ICT in Teaching and Learning of Health Education in Elementary Schools in Lagos State, Nigeria

\section{Introduction}

In the way and manner we tend to use technology across the globe, we may want to evaluate the usefulness of information and communication technology in an educational context, we also need to research how ICT can afford the processes of learning and what learning system can be achieved. As well, evaluating the impact of an ICT innovation in teaching and learning process is highly commendable. This gives a broad overview of issues surrounding the evaluation of the effectiveness of information and Communication Technology environment (Ayotunde, 2010). In consonance to Information and Communication Technology (ICT) media techs are used in modern schools especially schools where ICT is given priority. These tools of ICT are effectively put in place to give vivid picture, true state, and clarity of ideas of matters relating to it.

The term Information and Communication Technology (ICTs) is very popular across the globe and gradually growing in developing countries like Nigeria. However, not many assess its impact and application to enhance the quality of teaching and learning of health education in our education institutions particularly in elementary schools. Information in its real sense is an entity that arises from a set of data which has been structured and deigned toward a particular audience upon which vital decisions may be made. More so, it also refers to as a processes data with a purpose. In his view, Adedoyin (2007) opined that information is the exchange of data between or among individuals or organizations. He further stated that, it is the process through which information, knowledge, ideas or messages are conveyed or transmitted from one source to another. It is also a way of human social life and it is as well impossible to be alive without communicating our existence and interaction with one another. Communication is a process of information exchange between two or more individuals in an attempt by an individual to persuade or influence the behaviour of the other individual.

The teaching of health education in elementary schools exposes and increase teachers' experience which in turn assists pupils to attain valuable and sound ethics which encourages in harnessing 114 A Journal of the Department of Health, Physical Education and Recreation 
healthy decisions and determination in future. (Adebare, 2012). However, the confidence and professionalism of teachers has been undermined and this has resulted in avoidance of their exercise. Research shows that generally there is little reference to many health education lesson and teachers (Ganthon, 2012).

Moreover, as important as the teaching of health education is in elementary school, so also is the use of Information and Communication Technology (ICT) amongst pupils in these schools stir up a great interest to the teaching and learning of health education. In this presents time teaching and learning of any subject must be encouraged with the introduction and use of Information and Communication Technology gadgets which cannot be over emphasized. Its usage has gone viral than expected. Teaching and learning in the 21 st century is not complete without making use of information and communication technology as a tool.

Health education is an important aspect of learning that cannot be substituted for other subject, especially in elementary schools. Health education in the elementary schools is the basis of acquiring knowledge and ideas about the health of an individual and the environment. However, the elementary school set-up consists mainly of pupils who are less knowledgeable about human health. According to Michael (2010) stated that, the impact and effectiveness of health education can never be traced for anything whatsoever; this is because the health of an individual's is paramount to his or her well being.

In his view, Adekunle (2012) stated that Instructional materials, information and communication technology (ICT) encompasses a broad range of technologies that complement the classroom learning environment and can dramatically increase a pupil's access to quick and updated information which is very vital. The question to "Know" "how much" or "how many" has always been an eloquent task that is yet to be answered. He further stated that the earliest report shows people whom has quickly developed methods of one-to-one correspondence to help them communicate about members and objects. 
The use and Impact of ICT in Teaching and Learning of Health Education in Elementary Schools in Lagos State, Nigeria

The role of technology in teaching and learning is rapidly becoming one of the most important and widely discussed issues in contemporary education policy (Rosen and Well, 1995; and Thierer, 2000). Most experts in the field of education agreed that, when properly used, information and communication technology hold great promise to improve teaching and learning in addition to shaping workforce opportunities. There is no doubt that computer can aid the instructional process and facilitate students' learning. Many studies have found positive effect associated with technology aided instruction (Burnett, 1994, and Fitzgerald and Warner, 1996).Nigeria does not only lack information infrastructure, it also lacked the human skills and knowledge to fully integrate ICT into secondary education. To use information and communication technology (ICT) in secondary schools in Nigeria, the need for locally trained workers to install, maintain and support these systems cannot be over emphasized.

In Nigeria also, most secondary school teachers lack the skills to fully utilize technology in curriculum implementation hence the traditional chalk and duster approach still dominates in secondary school pedagogy. Information transfer using ICT is minimal or non-existence in secondary schools in Nigeria (Anao, 2003). Secondary school teachers in Nigeria need to be trained on educational technologies and the integration of computers into classroom teaching. According to Carlson and Firpo (2001), "teachers need effective tools, techniques, and assistance that can help them develop computer based projects and activities especially designed to raise the level of teaching in required subjects and improve student learning.

The price of computer hardware and software continues to drop in most developed countries, but in developing countries, such as Nigeria, the cost of computers is several times more expensive. The importance of ICT is quite evidence from the educational perspective. Though the chalkboard, textbooks, radio/television and film have been used for educational purpose over the years, none has quite impacted on the educational process like the computer. 
While television and film impact only on the audiovisual faculties of users, the computer is capable of activating the senses of sight, hearing and touch of the users. ICT has the capacity to provide higher interactive potential for users to develop their individual, intellectual and creative ability. The main purpose of ICT use"consists just in the development of human mental resources, which allow people to both successfully apply the existing knowledge and produce new knowledge" (Shavinina, 2001,).

\section{Research Hypothesis}

The following hypotheses were tested:

There is no significant use and impact of Information and Communication Technology in teaching and learning of health education in elementary schools in Lagos State, Nigeria There is no significant availability of Information and Communication Technology gadgets in teaching and learning of health education in elementary schools in Lagos State, Nigeria There is no significant effect of adequate personnel in teaching and learning of health education in elementary schools in Lagos State, Nigeria.There is no significant availability of funds for the teaching and learning of health education in elementary schools in Lagos State, Nigeria

\section{Methodology}

\section{Sample and Instrumentation}

The descriptive survey design was used for the study; the population comprised 1826 teachers of Elementary schools in Lagos State Nigeria. The instrument used for the study was a self developed structured questionnaire validated by experts in the field of Health Promotion and Educational Evaluation. The instrument was pre-tested using 50 elementary school teachers in Ogun state, Nigeria

\section{Data Collection and Analysis}

The instrument was personally administered on the respondents by the researchers, using some of the teachers as research assisstants. 1950 questionnaires were administered using purposive sampling 
The use and Impact of ICT in Teaching and Learning of Health Education in Elementary Schools in Lagos State, Nigeria

technique to select the respondents and stratified technique to select the schools; the questionnaire had a brief introduction on it which included the consent of the respondents to allow them respond and understand the essence of the study. The instrument was collected and collated and it was observed that only 1826 can be used for further analysis. The shortage was due to respondents' mortality or those instruments that were not properly filled. Data were analyzed using mean, std deviation and ANOVA.

Table 1: Showing the overall response of sampling (mean) from teachers in different elementary Schools in Lagos State

\begin{tabular}{|c|c|c|c|}
\hline Variables & Mean & Std Deviation & $\mathrm{N}$ \\
\hline Use and Impact & 3.7514 & .7339 & 1826 \\
\hline $\begin{array}{l}\text { Availability of } \\
\text { ICT }\end{array}$ & 3.5323 & .9347 & 1826 \\
\hline $\begin{array}{l}\text { Adequate } \\
\text { Personnel }\end{array}$ & 9.5520 & .7048 & 1826 \\
\hline $\begin{array}{l}\text { Availability of } \\
\text { Funds }\end{array}$ & 1.1172 & .6062 & 1826 \\
\hline
\end{tabular}

Table one above shows that 1826 respondents answered the instrument, After collecting the data from the respondents, the analysis was carried out and it was observed that usage and impact of ICT as a dependent variable is 3.75144 , and regarding to this variable respondent deviate from their mean equal to 0.7339 , this shows that the respondents agree that usage of ICT brings a positive impact on the teaching and learning of Health education in elementary schools thus helping to improve their knowledge and skills in the delivery of their duties.

Adequate Personnel as an independent variable is 9.5520 and regarding to this variable respondents deviate from a mean equal to 0.7048 this indicates that most of the schools lack professionally trained personnel to handle the installation and maintenance of these ICT gadgets while it was also observed that most personnel for health education were inadequate to take on the subject efficiently using modern Technology. The few personnel on 
ground believe that the use of ICT provides information to operate different devices and help to produce the productive knowledge that related to current studies, they are also agree that ICT in education sector provides knowledge that is helpful at the professional level.

Availability of funds for the procurement of ICT as an independent variable is 1.1172 and regarding to this variable respondents deviate from a mean equal to 0.6062 . This result shows that there are no funds for the purchase of ICT gadgets which often bring about inadequacies in teaching and learning. More so, there is the need for the purchase of Equipped ICT lab, internet in computer lab, use of multimedia during teaching as well as digital computer laboratory for the effective teaching and learning of Health Education.

\section{Table 2: Correlation of variables}

\begin{tabular}{|c|c|c|c|c|}
\hline Variables & $\begin{array}{l}\text { Use } \\
\text { Impact }\end{array}$ & $\begin{array}{l}\text { Availability of } \\
\text { ICT }\end{array}$ & $\begin{array}{l}\text { Adequate } \\
\text { Personnel }\end{array}$ & $\begin{array}{l}\text { Availability } \\
\text { Funds }\end{array}$ \\
\hline $\begin{array}{l}\text { Use } \\
\text { Impact }\end{array}$ & 1.000 & .876 & .894 & .567 \\
\hline $\begin{array}{l}\text { Availability } \\
\text { of ICT }\end{array}$ & .876 & 1.000 & .543 & .136 \\
\hline $\begin{array}{l}\text { Adequate } \\
\text { Personnel }\end{array}$ & .894 & .543 & 1.000 & .631 \\
\hline $\begin{array}{l}\text { Availability } \\
\text { of Funds }\end{array}$ & .567 & .136 & .631 & 1.000 \\
\hline
\end{tabular}

Table 2 above shows the inter dependence of variables on each other. Table shows lot of relationship between all the variables, availability of ICT and its usage and also its impact in Health education. More so, there was a correlation which indicates the use of ICT as 0.894 which indicates a change recorded in its use and impact. It was also observed that there was a good relationship with in availability of fund and usage and impact which indicates 0.567 with adequate personnel indicating a relationship of 0.631 . 
The use and Impact of ICT in Teaching and Learning of Health Education in Elementary

Schools in Lagos State, Nigeria

Table3: ANOVA showing joint effects of Variables

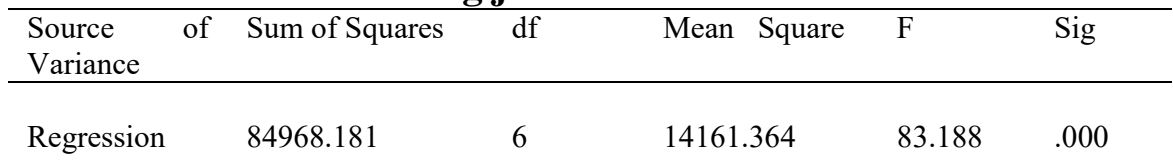

$\mathrm{R}=0.464$

$\mathrm{R}$ square $=0.215$

Adjusted R square $=0.213$

Table 3 shows that the joint effects co-efficient $\mathrm{R}$ between use and impact of ICT on other variables is 0.464 . Estimated $\mathrm{R}$ square equals 0.215 while Adjusted R square equals 0.213 . This simply means that the Use and Impact of ICT when taken together accounts for 22 percent variation in the teaching and learning of Health education in elementary schools. Further investigation on the joint effect regression produced $\mathrm{F}(6.1819)=83.188, \mathrm{P}<0.05$. Since $\mathrm{P}$ value is less than 0.05 , the null hypothesis is therefore rejected.

\section{Table 4: Showing relative coefficients of variables}

\begin{tabular}{|c|c|c|c|c|c|}
\hline \multirow[t]{2}{*}{ Variable } & \multicolumn{2}{|c|}{$\begin{array}{l}\text { Unstandardized } \\
\text { Coefficient }\end{array}$} & \multirow{2}{*}{$\begin{array}{l}\text { Standardized } \\
\text { Coefficient }\end{array}$} & \multirow[t]{2}{*}{$\mathrm{t}$} & \multirow[t]{2}{*}{ Sig } \\
\hline & B & $\begin{array}{l}\text { Std } \\
\text { Error }\end{array}$ & & & \\
\hline Use and Impact & 0.315 & .063 & .113 & 4.958 & .000 \\
\hline Availability of ICT & $2.788 \mathrm{E}-02$ & .145 & .005 & 2.193 & .847 \\
\hline Adequate Personnel & -1.320 & .207 & -232 & -4.370 & .000 \\
\hline $\begin{array}{l}\text { Availability of } \\
\text { Funds }\end{array}$ & 1.543 & .147 & .395 & 10.522 & .000 \\
\hline
\end{tabular}

Table 4 shows the efficiency of Independent Variables with Dependent variable. The value of ' $t$ ' for first independent variable i.e. Availability of ICT is 2.193 which shows that it is a very efficient variable. Also the value of ' $t$ ' for Adequate Personnel is 4.370 which shows its less efficient this indicates that if there are 120 A Journal of the Department of Health, Physical Education and Recreation 
available ICT gadgets then excess personnel may not be required thus promoting the teaching and learning of Health Education in elementary schools efficiently. Now the value of $t$ ' for Availability of funds is 10.522 which shows that it is a more efficient variable which is highly needed for the stability of the other variables which encompasses purchase and maintenance

\section{Discussion}

According to the findings in the study, it revealed that the availability and usage of ICT Gadgets has a significant use in the teaching and learning of health education in elementary schools which will enhance acquisition of knowledge, the results also indicates that it will improve the capacity and programme delivery of Health education teachers. The result is in line with the study of Wasif Nisar, Ehsan Ullah Munir and Shafqat Ali Shad (2011) who observed that availability and usage of ICT is very essential to improve the educational efficiency of students, they further stated that the availability of ICT in Education is supportive for the students to improve their learning skills as well as helps utilize latest technologies of ICT which are helpful for the students to better prepare their assignments and projects.

According to Ayodele (2012), he posits that information and communication technology cannot be over emphasized in today's teaching and learning especially in health education. Consequently, Ganthon (2012) supports this assertion when he claims that the era of theoretical basis of teaching health education is over, the world has been digitalized and health education is not left behind. More so, it was observed that despite the importance of Personnel, that available ICT gadget will help students develop themselves and it will promote their ability of self development and academic prowess. Going by the findings of this study,

Aduwa-Ogiegbaen and Iyamu (2005) citing Thomas (1987) stated that Today, computers perform a host of functions in teaching and learning as many nations are adding computer literacy, reading and writing literacy as skills students will need for succeeding in a technologically developed world . 
The use and Impact of ICT in Teaching and Learning of Health Education in Elementary Schools in Lagos State, Nigeria

Considering the findings concerning the availability of funds, it was observed that there is the need for the funding of ICT gadgets in schools which can enhance the interest of both the learner and the teachers in the area of Health education. The result is in line with the write up of Aduwa-Ogiegbaen and Iyamu (2005) who obderved that the price of computer hardware and software continues to drop in most developed countries, but in developing countries, such as Nigeria, the cost of computers is several times more expensive. While a personal computer may cost less than a month's wages in the United States, the average Nigeria worker may require a savings of about a year' income to buy one.

\section{Conclusion}

There is no doubt that teachers and students in schools in Nigeria will have incredible resources available if they have access to modern ICT gadgets. By integrating information and communication technology into health Education, thus the availability and usage of ICT is very essential to improve the teaching and learning of health education in elementary schools in Lagos Nigeria.

\section{Recommendations}

Based on the outcome of the study, the following recommendations were made:

There is the need for Government to provide adequate funds for the purchase of ICT gadgets and needed software equipment that will enhance and promote the teaching of Health education among students, thereby eliminating future spending on Health facilities. Non Governmental organizations should come to the aid of these schools by supplying and helping out with some needed ICT gadget that can enhance students learning of Health education.

There is the need for the recruitment of adequate personnel for the handling of the ICT gadgets when provided and more so, such personnel should be trained and retrained for the handling and maintenance of such gadgets. 


\section{References}

Adebare, P.P. (2012) A Handbook on ICT and its Application, Ilorin, Published by Deoti Publising Ventures.

Adebola, R.O. (2010) Essence of using computer gadgets to teach children in Nigeria. Journal of Cultural Education 6 (2) $56-62$.

Adedoyin, S.T. (2007) Enhancing classroom knowledge in Teaching and Learning Process. Journal of Education and Technology 8 (3) 112-117

Aduwa-Ogiegbaen, S. E., \& Iyamu, E. O. S. (2005). Using Information and Communication Technology in Secondary Schools in Nigeria: Problems and Prospects. Educational Technology \& Society, 8 (1), 104-112.

Anao, A. R. (2003). Society, knowledge incubation and management - Lagos. The Guardian Newspapers, November 11, 75.

Burnett, G. (1994). Technology as a tool for urban classrooms. ERIC/CUE Digest, 95, New York: Eric Clearing house on Urban Education, from http://www.ericdigests.org/1994/tool.htm.

Carlson, S., \& Firpo, J. (2001) Integrating computers into teaching: Findings from a 3-year program in 20 developing countries. In L. R Vandervert, L. V. Shavinina \& R. A. Cornell (Eds.), Cyber education: The future of Distance Learning. Larchmont, NY: Mary Ann Liebert, Inc, 85-114.

Fitzgerald, G., \& Werner, J. (1996). The use of the computer to support cognitive behavioural interventions for students with behavioural disorders. Journal of Computing in Childhood Education, 7, 127-48.

Ganthon,M .G.(2012) Technology and Science Education: An antidote to academic boredom. Journal of Education and Technology 8 (3) 87-91

Okebukola, P. (1997). Old, new and current technology in education. UNESCO Africa, 14 (15), 7-18. 
The use and Impact of ICT in Teaching and Learning of Health Education in Elementary Schools in Lagos State, Nigeria

Shavinina, L. V. (2001). A new generation of educational multimedia: High intellectual and creative educational multimedia technologies. In L. R Vandervert, L. V. Shavinina \& R. A. Cornell (Eds.), Cyber education: The future of Distance Learning. Larchmont, NY: Mary Ann Liebert, Inc, 63-82.

Thierer, A. (2000). Divided over the digital divide, Washington, DC: Heritage Foundation.

Thomas, R. M. (1987). Computer technology: An example of decision-making in technology transfer. In R. M. Thomas \& V. N. Kobayashi (Eds.), Educational technology: its creation, development and crosscultural transfer, Oxford: Pergamon Press, 25-34.

Tondeur, J., M. Valcke and J. Van Braak, 2008. A multidimensional approach to determinants of computer use in primary education: teacher and school characteristics; Journal of Computer Assisted Learning.

Wasif Nisar,M, Ehsan Ullah Munir and Shafqat Ali shad(2011) Usage and Impact of ICT in Education Sector; A Study of Pakistan. Australian Journal of Basic and Applied Sciences, 5(12): 578-583, 2011 